cidentally learned that the only species of Scyllarus known to Fabricius* in 1775 , when he first made known that genus, was the $S$. arctus -the Cancer arctus of Linnæus. That, being the only species, is necessarily the type, and, therefore, the name Scyllarus must be retained for it. The early carcinologists (Latreille, White) correctly recognized the type. Nevertheless, the $S$. arctus was taken as the type of a new genus-Arctus-and the name Scyllarus was reserved for the "Sc. 8culptus, latus, squamosus, equinoxialis, Haanii, Sieboldi," by Dana in 1852. He was doubtless influenced in this respect by the consideration that the arctus was the only species of its genus known to him, while most belonged to the other one. All succeeding carcinologists have followed him, and, indeed, the family is one of the very few for which a classification proposed nearly half a century ago has been retained intact to the present time, new species only having been added meanwhile. However, the necessity for a change will be recognized by almost every zoologist, and the sooner it is made the better it will be. I, therefore, propose to restore Scyllarus to the typical species, and to give the new name Scyllarides (Scyllarus with the Greek patronymic termination -ides) to the bereft genus. Scyllarides may be typified by the $S$. xquinoctialis (Scyllarus æquinoctialis of Nicolaus Tönder Lund). $\dagger$

According to Dr. Ortmann (Zool. Jahrb., Syst., 268, X., 1897), there are five well defined species of Scyllarides-squamosus, latus, haani, xquinoctialis and elizabethi.

W ASHINGTON.

Theo. Gill.

\section{LAMARCK AND 'A PERFECTING TENDENCY.'}

Profegror John Gardiner has done well to recall the fact that the chief factor in evolution,

* Systema Entomologiæ, p. 413, 1775.

† The proper authority for the species (generally known as ' $S$. æquinoxialis Fabr.') has been given by Miss Rathbun in the Annals of the Institute of Jamaica (I., 43). The excellent memoir of Lund (Om Slaegten Soyllarus < Skrivter af Naturh. Selskabet, II., p. 17-22, 1793) has been ignored by almost all othens. It was referred to by White, but the references to Land were mostly given after those to Fabrieius: according to Lamarck, is not the so-called ' $\mathrm{La}$ marckian factor,' but ' $a$ perfecting tendency.' Lamarck's Histoire Naturelle is in perfect accord with his Philosophie Zoologique, as interpreted by Professor Gardiner. Lamarck thus describes his two factors: (1) 'Composition progressive,' 'progression,' 'plan de la nature,' "pouvoir qui tend sans cesse à compliquer l'organisation, d̀ accroître le nombre et le perfectionnement des facultés," "cause première et prédominante." (2) "La cause accidentelle n'ayant pu alterer la progression en question, que dans des particularités de détail, et jamais dans la genéralité des organisations."

The editors of the second edition of the Histoire Naturelle add a foot-note (Vol. I., p. 114) which concisely states Lamarck's position : " Il y a donc, d'après Lamarck, deux causes toujours agissantes sur les animaux, l'une qui tend a les perfectionner d'une manière uniforme dans leur organisation, l'autre modifiant irrégulièrement ces perfectionnements, parcequ'elle agit selon les circonstances locales, fortuites, de température, de milieu, de nourriture, etc., dans lesquels les animaux vivent nécessairement."

Lamarck repudiates the 'échelle graduée' of Bonnet, and claims there is no identity between it and his 'composition progressive.'

\section{O. Whitman.}

\section{SCIENTIFIC LITERATURE.}

Recent and Coming Eclipses. By SIr NormaN. LoCkYER, K.C.B., F.R.S. Macmillan \& Co. 1897.

This volume, consisting mainly of articles which have appeared from time to time in current periodicals, is issued with a view to supplying the general reader with information regarding the latest phases of the chief eclipse problems.

The treatment divides itself into two parts. The earlier chapters of the work contain elementary explanations of the theory of eclipses, and that of the instruments used in their observation. The spectroscope in its various forms is discussed in detail, and much stress is laid on the efficiency of the slitless spectroscope or 'prismatic camera.' The application of this 